\title{
0959 LACK OF ADEQUATE ROAD FURNITURE IN NIGERIA - CONSEOUENCES AND SOLUTIONS
}

0 Olawepo* Correspondence: Highway Safety Initiative, Suite 7, Block J, Sky Memorial Complex Wuse Zone 5, Abuja, Nigeria

10.1136/ip.2010.029215.959

Situation reliable reports conducted by the World Bank transport department on the state of roads in Sub Saharan Africa between 1998 and 2008 confirmed a gross inadequacy of road furniture for safety of road users. Specifically, in the West African region, previous credible studies showed that no country with the exception of Ghana took broad steps to install appropriate and near adequate road furniture in $20 \%$ of the existing roads. In the past 10 years, the worsening state of Nigerian roads and lack of adequate road furniture have been of concern for road users especially given its attendant threat to lives and safety of road users.

Objective To investigate the inadequacy of road furniture on Nigeria roads and make recommendations.

Method Investigation was conducted on three major highways in Abuja, the Federal Capital City of Nigeria, Lagos, the commercial centre and Ilorin, a state capital. Questionnaires were distributed to 10 Federal Road Safety Officials. The existence of road furniture was examined.

Conclusion The study revealed gross absence of road furniture, $50 \%$ of Federal Road Safety officials interviewed in this study suggest that the absence of road furniture in Nigeria is grossly contributing to the high incidence of road traffic crashes. The Federal Road Safety Commission and road development agencies should give this issue a priority and help reverse the trend of absence of road furniture in Nigeria. 